\title{
Особенности образования ультракалиевых алюмосиликатных расплавов на примере сынныритов Сыннырского массива
}

Панина Л. И., Рокосова Е. Ю., Рябуха М. А.

\begin{abstract}
Аннотация
С целью выяснения условий образования сынныритов на Сыннырском щелочном плутоне были изучены расплавные включения в минералах шонкинитов, псевдолейцитовых сиенитов, в апатите из апатитовых обособлений, присутствующих в пироксенитах, шонкинитах и сынныритах, а также в минералах более поздних даек мончикитов-камптонитов. Установлено, что все плутонические породы массива образовались из одной материнской щелочнобазальтоидной магмы в процессе длительной кристаллизационной дифференциации и фракционирования в условиях закрытой системы, исключающей отход летучих компонентов. Одноименные минералы в породах кристаллизовались при близких температурах, в одной и той же последовательности: клинопироксен $\left(1280-1150^{\circ} \mathrm{C}\right) \rightarrow$ лейцит $\left(1250-1200^{\circ} \mathrm{C}\right) \rightarrow$ калиевый полевой шпат $\left(1200-1180^{\circ} \mathrm{C}\right)$ $\leftrightarrow$ апатит (выше 1180-1050 C) $\rightarrow$ нефелин, кальсилит. Состав материнской магмы в ходе кристаллизации эволюционировал в сторону увеличения $\mathrm{Si}, \mathrm{Al}, \mathrm{K}$ и уменьшения $\mathrm{Fe}, \mathrm{Mg}$, Ca, т.е. в сторону мелафонолитовых и фонолитовых расплавов. Широкое проявление процессов дифференциации и фракционирования позволило минералам разделиться в соответствии с их удельным весом: тяжелые минералы (клинопироксен, рудные, апатит) опускались на дно магматической камеры, формируя нижнюю меланократовую серию, а легкие (лейцит, калишпат, фоиды) вместе с остаточным расплавом скапливались на верхних горизонтах камеры, образуя верхнюю лейкократовую серию породы. В процессе кристаллизации в расплавах увеличивалось количество флюидов, в которых при 920-830 C содержалось 3033-4051 мг/кг СО2, 397-644 мг/кг Н2О и 42.7-83.7 мг/кг СО. На ранней высокотемпературной стадии, когда количество флюидов было незначительно, тренд преобразования магмы совпадал с трендом кристаллизации базальтоидов. Об этом свидетельствуют температуры гомогенизации и химический состав включений в минералах мончикитов-камптонитов, аналогичные таковым в плутонических породах массива. Кристаллизация клинопироксена в дайковых породах происходила при 4.58 кбар на глубине 10-12 км. На стадии кристаллизации полевых шпатов, когда количество флюидов в расплавах при формировании плутонических пород массива значительно возрасло, а при образовании базальтоидов, наоборот, резко упало, их тренды стали разными. Тренд кристаллизации базальтоидов был направлен в сторону трахитовых расплавов с увеличением в них $\mathrm{Si}$ и уменьшения $\mathrm{Fe}, \mathrm{Mg}$, щелочей. При формировании плутонических пород массива высокое давление воды препятствовало образованию плагиоклаза, расплавы становились все более обогащены Al, K, приобретали все более высокоглиноземистый ультракалиевый состав, из которого на завершающих стадиях преобразования кристаллизовались сынныриты кальсилитнефелин-калишпатового состава.

Сделан вывод, что сынныриты кристаллизовались в температурном диапазоне несколько превышающем $1050-1180^{\circ} \mathrm{C}$ из остаточных продуктов дифференциации и фракционирования щелочнобазальтоидной магмы в замкнутых условиях, исключающих потерю летучих компонентов. Редкая встречаемость сынныритов связана с ограниченными возможностями появления в природе замкнутых магматических камер - макроаналогов включений минералообразующих сред в минералах.
\end{abstract}

Ключевые слова: сынныриты, меланократовые породы, апатитовые обособления, расплавные включения, щелочнобазальтовая магма, летучие компоненты, вода, замкнутая камера. 


\title{
Особенности образования ультракалиевых алюмосиликатных расплавов на примере сынныритов Сыннырского массива
}

\author{
Л.И. Панина, Е.Ю. Рокосова, М.А. Рябуха \\ Институт геологии и минералогии СО РАН им. В.С.Соболева, \\ 630090, Новосибирск, просп. Академика Коптюга, 3, Россия
}

\begin{abstract}
Аннотация
С целью выяснения условий образования сынныритов на Сыннырском щелочном плутоне были изучены расплавные включения в минералах шонкинитов, псевдолейцитовых сиенитов, в апатите из апатитовых обособлений, присутствующих в пироксенитах, шонкинитах и сынныритах, а также в минералах более поздних даек мончикитов-камптонитов. На основании установленных и ранее полученных данных сделано заключение, что все плутонические породы массива образовались из одной материнской щелочнобазальтоидной магмы в процессе длительной кристаллизационной дифференциации и фракционирования в условиях закрытой системы, исключающей отход летучих компонентов. Одноименные минералы в породах кристаллизовались при близких температурах, в одной и той же последовательности: клинопироксен $\left(1280-1150^{\circ} \mathrm{C}\right) \rightarrow$ лейцит $\left(1250-1200^{\circ} \mathrm{C}\right) \rightarrow$ калиевый полевой шпат $\left(1200-1180^{\circ} \mathrm{C}\right) \leftrightarrow$ апатит (выше $1180-$ $\left.1050^{\circ} \mathrm{C}\right) \rightarrow$ нефелин, кальсилит. Состав материнской магмы в ходе кристаллизации эволюционировал в сторону увеличения $\mathrm{Si}, \mathrm{Al}, \mathrm{K}$ и уменьшения $\mathrm{Fe}, \mathrm{Mg}$, Ca, т.е. в сторону мелафонолитовых и фонолитовых расплавов. Широкое проявление процессов дифференциации и фракционирования позволило минералам разделиться в соответствии с их удельным весом: тяжелые минералы (клинопироксен, рудные, апатит) опускались на дно магматической камеры, формируя нижнюю меланократовую серию, а легкие (лейцит, калишпат, фоиды) вместе с остаточным расплавом скапливались на верхних горизонтах камеры, образуя верхнюю лейкократовую серию пород. В процессе кристаллизации в расплавах увеличивалось количество флюидов, в которых при 920-830 ${ }^{\circ} \mathrm{C}$ содержалось 3033-4051 мг/кг $\quad \mathrm{CO}_{2}$, 397-644 мг/кг $\quad \mathrm{H}_{2} \mathrm{O} \quad$ и 42.7-83.7 мг/кг СО. На ранней высокотемпературной стадии, когда количество флюидов было незначительно, тренд преобразования магмы совпадал с трендом кристаллизации базальтоидов. Об этом свидетельствуют температуры гомогенизации и химический состав включений в минералах мончикитов-камптонитов и щелочных базальтоидов, аналогичные таковым в плутонических породах массива. Кристаллизация клинопироксена в дайковых породах происходила при 4.58 кбар на глубине 10-12 км. На стадии кристаллизации полевых шпатов, когда количество флюидов в расплавах при формировании плутонических пород массива значительно возрасло, а при образовании базальтоидов, наоборот, резко упало, их тренды стали разными. Тренд кристаллизации базальтоидов был направлен в сторону трахитовых расплавов с увеличением в них $\mathrm{Si}$ и уменьшения $\mathrm{Fe}, \mathrm{Mg}$, $\mathrm{Al}$, щелочей. При формировании плутонических пород массива высокое давление воды препятствовало образованию плагиоклаза, расплавы становились все более обогащены $\mathrm{Al}, \mathrm{K}$, приобретали
\end{abstract}


все более высокоглиноземистый ультракалиевый состав, из которого на завершающих стадиях преобразования формировались сынныриты кальсилит-нефелин-калишпатового состава.

Сделан вывод, что сынныриты кристаллизовались в температурном диапазоне несколько превышающем $1050-1180^{\circ} \mathrm{C}$ из остаточных продуктов дифференциации и фракционирования щелочнобазальтоидной магмы в замкнутых условиях, исключающих потерю летучих компонентов. Редкая встречаемость сынныритов связана с ограниченными возможностями появления в природе замкнутых магматических камер макроаналогов включений минералообразующих сред в минералах.

Ключевые слова: сынныриты, меланократовые породы, апатитовые обособления, расплавные включения, щелочнобазальтовая магма, летучие компоненты, вода, замкнутая камера.

\section{Введение}

Сынныриты являются очень редкими породами-рудами. Они представляют собой гололейкократовую плотную породу, состоящую из калиевого полевого шпата (55-85 об. \%), кальсилита (до 35 об.\%), нефелина (до 10 об. \%) и редких зерен биотита (1-2 об.\%). В химическом составе сынныритов присутствует до 22-23 мас.\% $\mathrm{Al}_{2} \mathrm{O}_{3}$ и 16.5-21 мас. \% $\mathrm{K}_{2} \mathrm{O}$, что позволяет использовать породы в виде комплексного сырья для получения глинозема и бесхлорных калийных удобрений. Сынныриты встречаются в составе ультракалиевых комплексных плутонов, где совместно с псевдолейцитовыми и нефелиновыми сиенитами слагают верхнюю лейкократовую серию пород. На массивах также присутствует нижняя мезо-, меланократовая серия, сложенная слюдяными пироксенитами, шонкинитами, реже оливин-монтичеллит-пироксеновыми породами (Маломурунский массив). Ультракалиевые комплексные массивы распространены преимущественно на территории России, главным образом в Байкало-Становой рифтовой системе Сибирского кратона [Костюк, 1990; Костюк и др., 1990]. Здесь они представлены Сыннырским, Якшинским и Сакунским высококалиевыми массивами, сформировавшимися в палеозойский этап магматизма. В меньшем количестве сынныриты отмечаются на Маломурунском, Ломамском и Дежневском вулкано-плутонах, образовавшихся в мезозойский период. За рубежом сынныритоносные массивы известны в Гренландии [Brooks et al., 1981] и Западном Регубатском поднятии Западного Африканского кратона, расположенного в южном Марокко и Мавритании [Bea et al., 2014]. Последние являются самыми древними образованиями (архейско-протерозойскими) и по размерам сопоставимы с Сыннырским массивом.

Относительно генезиса сынныритов нет однозначного представления. Уникальность их химического состава, который приближается к составу лейцита, способствовала появлению противоречивых гипотез. Так происхождение сынныритов в Регубатском поднятии Западного Африканского кратона исследователи [Bea et al., 2014] объясняют следующим образом. Они считают, что вначале под уже стабилизированной архейской корой региона кристаллизовалась при 10-16 кбар обедненная водой мафическая ультракалиевая магма. Из неё около $1100^{\circ} \mathrm{C}$ начинал кристаллизоваться лейцит, который всплывал в верхнюю часть магматической камеры. Позже в камеру внедрилась более натровая богатая водой магма, возникшая в той же части источника метасоматизированной мантии. На заключительных этапах кристаллизации от нее отделилась водная паровая фаза, которая расплавила лейцитовую шапку, превращая её в низкоплотную 
водосодержащую магму сынныритового состава. Кристаллизация последней обусловила возникновение сынныритов и нефелиновых сиенитов. Относительно происхождения сынныритов в ультракалиевых массивах, присутствующих на территории России, существуют другие представления. А.Я. Жидков [1980, 1986] допускает возможность возникновения в природе материнских ультракалиевых расплавов, из которых могли кристаллизоваться сынныриты. Г.В. Андреев [1965] считает, что подобные расплавы могли возникнуть в результате расплавления скопившегося в верхних частях магматической камеры лейцита в процессе медленного остывания исходного расплава. Более обоснованной является гипотеза образования сынныритов из калиевой щелочнобазальтоидной магмы в результате длительных процессов ее дифференциации и фракционирования в специфических условиях, приближенных к закрытым системам, исключающих отход летучих компонентов, прежде всего $\mathrm{H}_{2} \mathrm{O}$ [Панина, 1983; Костюк и др., 1986; 1990]. На закрытость системы и обогащенность расплавов водой при формировании ультракалиевых плутонов, по их мнению, свидетельствует присутствие биотита и роговой обманки в меланократовых породах и среди дочерних фаз расплавных включений в минералах. Главным доказательством щелочнобазальтоидного состава исходных расплавов явилось присутствие в частично раскристаллизованных включениях в клинопироксенах разных по возрасту и местонахождению калиевых щелочных базальтоидов остаточных стекол, близких по составу к высокоглиноземистым, богатым калием сиенитам и сынныритам [Базарова и др., 1981; Чепуров и др., 1974]. Было сделано предположение, что расплавы подобного состава могут возникнуть при кристаллизационной дифференциации щелочнобазальтоидной магмы в условиях замкнутых магматических камер - макроаналогов расплавных включений в минералах.

В целом о генетической связи щелочнобазальтоидной магмы с ультракалиевыми сынныритоносными массивами, по мнению исследователей, свидетельствуют многие факты: а) один и тот же набор высокотемпературных минералов за исключением полевых шпатов, которые в базальтоидах представлены плагиоклазом, а в плутонических породах калиевым полевым шпатом; б) близкие температуры и порядок кристаллизации одноименных минералов; в) один и тот же тренд преобразования законсервированных в минералах высокотемпературных расплавов, который во всех случаях направлен в сторону увеличения $\mathrm{Si}, \mathrm{Al}$, щелочей и уменьшения $\mathrm{Mg}$, Fe, Ca; г) близость химического состава остаточных стекол в частично раскристаллизованных включениях в клинопироксене щелочных базальтоидов составу высокоглиноземистых, богатых калием сиенитов и сынныритов.

Вместе с тем прямые доказательства наличия большого количества летучих компонентов (особенно воды) при формировании сынныритов отсутствовали. Требовались также получить прямые доказательства образования расплавов, отвечающих составу сынныритов, в процессе эволюции щелочнобазальтоидной магмы. Чтобы получить подобную информацию, мы попытались исследовать на Сыннырском плутоне включения в минералах меланократовых пород, присутствующих на массиве в виде крупных блоков шонкинитов и слюдистых пироксенитов и являющихся фрагментами нижней породной серии, а также изучить включения в калиевом полевом шпате псевдолейцитовых сиенитов и в апатите из пироксен-биотит-магнетит-апатитовых обособлений в слюдистых пироксенитах, шонкинитах и сынныритах. Все перечисленные плутонические породы и обособления, по мнению исследователей [Костюк, 1983; Костюк и др., 1986; Панина и др., 
1991; Шарыгин, Панина, 1993], генетически между собой связаны и являются производными родоначальной щелочнобазальтоидной магмы, кристаллизовавшейся в закрытых условиях. Следовательно, полученная информация должна отразить эволюционное преобразование последней и зафиксировать, как ранее предполагалось [Панина, 1983; Костюк и др., 1990], появление ультракалиевых высокоглиноземистых расплавов на завершающих стадиях её кристаллизации.

Кроме того, нами были исследованы присутствующие в пределах массива более молодые дайки мончикитов-камптонитов, относящиеся априори $\mathrm{k}$ производным щелочнобазальтоидных магм. Мы полагаем, что изучение даек позволит выявить особенности преобразования щелочнобазитовой магмы при кристаллизации в более открытой магматической системе и сравнить полученные результаты с таковыми при формировании плутонических пород массива.

Для выяснения состава и количества флюидов, присутствующих в ультракалиевых расплавах, мы также провели хроматографические исследования сынныритов.

\section{Геологическое строение Сыннырского массива}

Сыннырский плутон входит в состав Северо-Байкальской щелочной провинции, приурочен к Байкальской рифтовой зоне, которая была заложена в архее. Глубинные разломы обновлялись в последующие эпохи и служили путями проникновения щелочных расплавов, среди которых магмы с калиевой специализацией играли превалирующую роль [Салоп, 1967; Архангельская, 1974]. Сыннырский массив занимает высокогорную часть одноименного хребта. В плане массив имеет изометричную форму с поперечным сечением до 25 км (рис. 1). По геофизическим и геологическим представлениям [Жидков, 1978; 1980; Костюк и др., 1990; Орлова и др., 1993] форма его грибообразная, лакколитовая. Массив сформирован в результате внедрения двух интрузивных фаз: ранней лакколитовой интрузии высококалиевых фоидитовых сиенитов, занимающей площадь около 500 км$^{2}$ и более позднего диапирового штока пуласкитов-гедрумитов площадью около 90 км². Шток расположен внутри лакколита и имеет заметное смещение к юго-западу относительно центра массива. Лакколит первой интрузивной фазы представляет собой зональнокольцевое тело. В нем выделяется три петрографо-петрохимические зоны: внешняя, промежуточная и внутренняя, контактирующая со штоком пуласкитов-гедрумитов. Внешняя зона сложена преимущественно нефелиновыми сиенитами (фойяитами, итсиндритами, дитроитами*) с высокими содержаниями $\mathrm{Al}_{2} \mathrm{O}_{3}$ (17.5-20 мас. \%) и щелочей (11-16 мас. \%) при преобладании калия над Nа. Вблизи северного эндоконтакта (р. Куйкипури) отмечается небольшое тело псевдолейцитовых сиенитов с содержанием $\mathrm{K}_{2} \mathrm{O}$ около 15 мас. \%. Внутренняя кольцевая зона лакколита сложена преимущественно сынныритами, содержащими 16-21 мас. \% $\mathrm{K}_{2} \mathrm{O}$ и 22-23 мас. \% $\mathrm{Al}_{2} \mathrm{O}_{3}$. Промежуточная зона лакколита имеет ассиметричное строение с изменением мощности от 2 до 7-8 км. Среди пород этой зоны отмечаются как дитроиты, так и псевдолейцитовые сиениты и сынныриты.

В породах ранней интрузивной фазы (преимущественно в сынныритах) эпизодически встречаются ультраосновные-основные меланократовые разности в виде тел

*Поскольку все работы по сынныритам в России проводились в 60-90 годы прошлого столетия и при описании употреблялась принятая в тот период классификация пород [Андреева и др., 1984], то для адекватного восприятия опубликованной в те годы литературы, мы сохранили и использовали те же названия пород. 
различной формы (шлиры, пласты, линзы, слои) и размера: от десятков сантиметров до нескольких метров мощностью и от десятков метров до 1-2 километров протяженностью.

Меланократовые породы представлены главным образом шонкинитами, реже слюдистыми пироксенитами. Большая часть шонкинитов сосредоточена в северовосточной части интрузии, на участке Калюмный. Тела шонкинитов залегают согласно с общим падением кольцевой структуры сынныритов, которые направлено к центру массива. Согласно исследованиям В.В.Шарыгина и Л.И. Паниной [1993] мелкие тела шонкинитов являются однородными. В наиболее крупных телах центральные зоны сложены слюдистыми пироксенитами мощностью до 0.5-3 м, которые сменяются по направлению к вмещающим сынныритам шонкинитами, переходящими в мелапуласкиты и пуласкиты. Сверху вниз по разрезу относительная мощность прослоев, обогащенных салическими минералами, уменьшается, а фемическими - увеличивается. Согласно геофизическим данным [Костюк и др., 1990; Панина и др., 1991], меланократовые породы слагают придонную часть магматической камеры и как на Сакунском и Маломурунском массивах, формируют нижнюю мезо-, меланократовую породную серию. В шонкинитах и слюдистых пироксенитах в виде гнезд, шлиров, прожилковых вкраплений обособляется апатит, ассоциирующий с клинопироксеном, биотитом, калиевым полевым шпатом, магнетитом. Апатитовые обособления слагают разнообразные, чаще неправильные по форме тела мощностью до нескольких метров и протяженностью до первых сотен метров. Подобные скопления апатита, но существенно в меньшем количестве и размерах, отмечаются также в псевдолейцитовых сиенитах и сынныритах.

Геологический возраст нефелиновых сиенитов и сынныритов, определенный рубидий-стронциевым методом, соответствует 330 $\pm 4-311 \pm 1$ млн. лет. Возраст пуласкитов второй интрузивной фазы, установленный калий-аргоновым методом, составляет $305 \pm 12$ млн лет [Костюк и др., 1990].

На массиве развита также поздняя дайковая серия калиевых базальтоидных пород, представленная мончикитами-камптонитами, которые приурочены к зонам долгоживущих глубинных разломов северо-западного простирания [Горстка, Крапивин, 1969]. Форма их пластинообразная с четкими резкими контактами, мощность 0.3-2 м, протяженность 50300 м, возраст 170-190 млн. лет.

Химический состав главных видов пород Сыннырского массива приведен в таблице № 1 по [Яшина, 1982; Костюк и др., 1990; Шарыгин, Панина, 1993].

\section{Краткая минералого-петрографическая исследуемых пород}

характеристика

Слюдяные пироксениты являются среднезернистыми породами, состоят из 65-70 об.\% идиоморфных зерен клинопироксена, 20-25 об.\% биотита, 3-5 об.\% зерен и хадакристаллов апатита, около 1 \% ограненных зерен магнетита и редких ксеноморфных зерен калиевого полевого шпата. Хадакристаллы апатита содержатся в зернах клинопироксена и биотита.

Шонкиниты имеют средне-, мелкозернистую, реже порфировидную структуру за счет присутствия пойкилокристаллов калиевого полевого шпата и амфибола. В своем составе они содержат 40-50 об.\% идиоморфных зерен клинопироксена, 15-20 об.\% биотита, 20-30 об.\% ксеноморфного калиевого полевого шпата, около 1 об.\% нефелина, до 
2 об.\% гипидиоморфных зерен апатита и магнетита. Иногда присутствует гранат (до 5 об. $\%)$.

Магнетит-биотит-апатитовые породы, образующие шлирообразные тела в пироксенитах, шонкинитах и сынныритах, характеризуются переменным минеральным составом. Центральные части тел представлены апатитом, либо биминеральным биотитапатитовым агрегатом. Периферийные части обычно содержат до 50 об.\% апатита, 25 об.\% биотита и 20-25 об.\% магнетита. В центральных и периферийных частях апатитовых тел иногда присутствует до 1-3 об.\% титанита и около 1 об.\% калиевого полевого шпата. Апатит в породе присутствует в виде крупных и разновеликих зерен, между которыми развиваются биотит, магнетит, калиевый полевой шпат, титанит.

Согласно исследованиям В.В. Шарыгина и Л.И. Паниной [1993], химический состав одноименных минералов в слюдяных пироксенитах, шонкинитах и магнетитбиотит-апатитовых рудах близкий. Клинопироксен отвечает составу диопсид-салита, содержит незначительную примесь эгиринового минала. В слюдяных пироксенитах минерал имеет более низкую железистость, чем в шонкинитах: $\mathrm{f}=23-35 \%$ против 39-56 \%. Биотит обогащен $\mathrm{TiO}_{2}$ (1.6-3.6 мас.\%) и $\mathrm{BaO}$ (0.5-2.1 мас.\%). Его железистость незначительно повышается от пироксенитов к шонкинитам (от 59.4 до 62.4 \%). Калиевый полевой шnam является калинатровой разновидностью. В его составе соотношение ортоклаза к альбиту меняется от 74:26 до 90:10. Минерал содержит до 1.5-3.0 мас. \% ВаО и 0.2-0.9 мас.\% SrO. Гранат представлен титанистым андрадитом-меланитом. Anaтum относится к F-апатиту, содержит 0.5-2.9 мас.\% SrO.

Псевдолейцитовые сиениты представлены [Костюк и др., 1990] плотной мелкозернистой породой с вкрапленниками псевдолейцита, иногда частично ограненными. Количество вкрапленников варьирует от 10-15 до 20-60 об.\%, размер - от 5 до 20 мм. Основным минералом породы является гипидиоморфный калиевый полевой шпат (9095\%), в разной степени проросший кальсилитом и нефелином. Более или менее идиоморфные зерна нефелина отмечаются в незначительном (1-2\%) количестве. В породе присутствует клинопироксен (диопсид-салит) и биотит, а также акцессорные: титанит, титаномагнетит, апатит.

Камптониты состоят из тонкозернистой основной массы и небольших вкрапленников клинопироксена, биотита, амфибола, оливина. В основной массе присутствует преимущественно плагиоклаз, а также клинопироксен, биотит, апатит, магнетит. Мончикит представлен вкрапленниками клинопироксена, амфибола, биотита, редкими зернами оливина и стекловатой основной массой, в которой присутствуют микролиты амфибола, клинопироксена и анальцима. По данным В.Н. Горстки и А.Г. Крапивина [1969] клинопироксен отвечает титанистому авгиту, а амфибол - баркевикиту.

\section{Методы исследования}

Для реконструкции физико-химических условий образования сынныритов Сыннырского массива наряду с традиционными геологическими, минералогическими и петрографическими методами мы широко использовали методы термобарогеохимии, которые основаны на изучении расплавных и флюидных включений, законсервированных в минералах в процессе их роста и охлаждения. Для гомогенизации включений была использована совмещенная с микроскопом термокамера с силитовым нагревателем, позволяющая нагревать включения до $1350-1400^{\circ} \mathrm{C}$ при постоянном контроле за 
происходящими изменениями во включениях. Эталонировка камеры осуществлялась по отчетливо фиксированным точкам плавления химически чистых солей и благородных металлов, помещенных в рабочую точку камеры. Точность измерения температуры составляла $\pm 10-15^{\circ} \mathrm{C}$. Из-за повышенной разгерметизации включений нагревание производилось очень медленно в течение 5-6 часов и часто прекращалось после расплавления последней дочерней фазы и некоторого уменьшения газового пузыря, и закалялось.

Для выяснения химического состава породообразующих минералов, дочерних фаз и стекла в прогретых и непрогретых включениях был использован микрозондовый анализ. Анализ проводился на рентгеноспектральном микроанализаторе «Camebax-micro» в ИГМ СО РАН. При анализе диаметр зондового пучка не превышал 2-3 мкм, ускоряющее напряжение составляло 20 кВ, ток 30-40 нА. В качестве эталонов использовались международные стандарты минералов и стекол. Точность анализа составляла $\pm 1.5 \%$. Для выяснения качественного и количественного состава летучих компонентов, присутствовавших в кристаллизовавшемся расплаве при определенных температурах, нами был использован метод газовой хроматографии, разработанный в ИГМ СО РАН. Метод позволяет из одной навески пробы количественно определить $\mathrm{CO}_{2}, \mathrm{H}_{2} \mathrm{O}, \mathrm{CO}, \mathrm{H}_{2}$, $\mathrm{O}_{2}+\mathrm{Ar}, \mathrm{N}_{2}, \mathrm{H}_{2} \mathrm{~S}, \mathrm{SO}_{2}$ и предельные углеводороды от метана $\left(\mathrm{CH}_{4}\right)$ до пентана $\left(\mathrm{C}_{5} \mathrm{H}_{12}\right)$. Суть метода заключается в регистрации газов, выделившихся из включений при их перегреве и разгерметизации. При анализе проба минерала или породы (200 мг, фракция 0.25-0.5 мм) помещается в капсулу и подключается к вакуумной системе. После откачки воздуха проба плавно нагревается до $1000^{\circ} \mathrm{C}$. В процессе прогрева происходит разгерметизация включений и выделение из них газа. Выделившийся газ вызывает падение вакуума в системе, которое фиксируется датчиком. С помощью термометра определяется температура нагревания образца и температура поступления газов в систему. Непрерывно работающий вакуумный насос откачивает поступающий газ в анализирующую систему, представленную тремя серийными хроматографами ЛХМ-80. Здесь происходит разделение газов на основе их различного физико-химического взаимодействия с сорбентом хроматографической колонки и осуществляется их качественное и количественное определение.

\section{Расплавные включения в минералах}

В клинопироксене шонкинитов, калиевом полевом шпате псевдолейцитовых сиенитов и апатите из апатитовых обособлений в рассматриваемых плутонических породах Сыннырского массива нами были обнаружены силикатные, солевые и газовожидкие включения, которые чаще всего встречаются совместно. Наибольшее количество включений присутствует в апатите, наименьшее - в калиевом полевом шпате. Силикатные включения встречаются преимущественно в клинопироксене и калиевом полевом шпате, в меньшем количестве - в апатите, в котором преобладают солевые включения. Силикатные и солевые включения располагаются в минералах бессистемно, иногда группами, изредка поодиночке, относятся к первичным. Газово-жидкие включения приурочены к сквозным трещинам в минералах, являются вторичными. Задачей нашего исследования явилось изучение первичных силикатных включений, присутствующих в минералах рассматриваемых пород. Солевым и газово-жидким включениям посвящена специальная статья Л. И. Паниной и Л.М.Усольцевой [2003]. 
Прежде чем перейти к рассмотрению силикатных включений в минералах, отметим их характерную особенность: независимо от присутствия включений в том или ином минерале и породе, большинство из них при нагревании взрывается, особенно при температурах, близких к гомогенизации содержимого. Это чрезвычайно затрудняло исследования, особенно при определении химического состава включений и существенно уменьшило объем полученной информации.

В клинопироксенах шонкинитов силикатные включения встречаются небольшими группами, до 7-10 штук в поле зрения. Клинопироксен представлен салитом (табл. 2, ан. 13). Форма включений разнообразная: удлиненная, изометричная, округлая. Размер варьирует от 3 до 15 мкм. Содержимое включений преимущественно тонко раскристаллизованное. Среди дочерних фаз включений установлен биотит (табл. 2, ан. 10) и кальцит (52.14 мас.\% $\mathrm{CaO}, 2.24$ мас.\% FeO, 2.01 мас.\% $\mathrm{SrO}$ ). В составе биотита отмечается около 3 мас.\% $\mathrm{TiO}_{2}$ и 0.4 мас.\% $\mathrm{BaO}$, а в кальците - до 2 мас.\% SrO. При нагревании содержимое включений начинает подплавляться около $760-780^{\circ} \mathrm{C}$, при $820^{\circ} \mathrm{C}$ оформляется газовый пузырь, полное плавление дочерних фаз осуществляется при 1180$1190^{\circ} \mathrm{C}$. При дальнейшем повышении температуры газовый пузырь вначале перемещается, а потом резко уменьшается в размерах и исчезает при $1235-1280^{\circ}$ С. Химический состав гомогенизированных включений отвечает составу мелафонолитов калиевого типа щелочности, содержит 0.5 - 1.2 мас. \% $\mathrm{TiO}_{2}$ (табл. 3, ан. 1-3).

В калиевом полевом шпате силикатные включения были изучены в псевдолейцитовых сиенитах. Состав калиевого полевого шпата практически безнатровый, содержит 2.4 мас.\% ВаO (табл.2, ан. 12). Включения в калиевом полевом шпате мелкие от 5 до 20 мкм, округлой, удлиненной и неправильной формы. Содержимое включений тонкораскристаллизовано, представлено бесцветными и зеленоватыми дочерними фазами, а также рудным минералом. Подплавление дочерних фаз отмечается около $800^{\circ} \mathrm{C}$. При дальнейшем повышении температуры рудная фаза округляется, появляется газовый пузырь. При $1000-1025^{\circ} \mathrm{C}$ дочерние фазы интенсивно расплавляются и большинство включений взрывается, появляются трещины в минерале. Гомогенизировать содержимое удалось в единичных, самых мелких включениях при $1180 \leq 1215^{\circ} \mathrm{C}$. Химический состав закаленных включений отвечает калиевым фонолитам (табл. 3, ан. 4) и близок составу дитроитов Сыннырского массива (табл. 1, ан. 6).

В апатите (табл. 2, ан. 13-15) из апатитовых обособлений в сынныритах, шонкинитах и слюдистых пироксенитах силикатные включения имеют неправильную и частично ограненную форму. Они преимущественно тонкораскристаллизованы. Газовый пузырь обычно отсутствует. Подплавление дочерних фаз во включениях наблюдается около $670-830^{\circ} \mathrm{C}$. При $750-860^{\circ} \mathrm{C}$ оформляется газовый пузырь. При $1000-1070^{\circ} \mathrm{C}$ дочерние фазы полностью расплавляются и при $1050-1180^{\circ} \mathrm{C}$ большинство включений взрывается. Можно полагать, что температуры гомогенизации включений незначительно превышают $1200^{\circ} \mathrm{C}$. Подобные температуры были ранее зафиксированы при гомогенизации включений в апатите, присутствовавшем в породах Сакунского, Маломурунского и Ханинского массивов [Панина и др., 1991]. Химический состав стекла включений, закаленных при температуре полного плавления дочерних фаз, изменяется от лейцитфонолитового (табл. 3, ан. 5-8) до остаточного ультракалиевого высокоглиноземистого (табл. 3, ан. 9-11), близкого, соответственно, составу псевдолейцитовых сиенитов и сынныритов рассматриваемого массива. 
Таким образом, полученные данные свидетельствуют, что сынныриты формировались из остаточных отдифференцированных расплавов ультракалиевого высокоглиноземистого состава в температурном интервале, незначительно превышающем $1050-1180^{\circ} \mathrm{C}$. Повсеместная разгерметизация расплавных включений в минералах рассматриваемых пород говорит о том, что расплавы были существенно обогащены флюидами еще на ранней магматической стадии и их количество в процессе кристаллизации не уменьшалось, а, наоборот, увеличивалось.

В дайках мончикитов-камптонитов включения были изучены в клинопироксене и амфиболе. Все они представлены силикатными разностями. В клинопироксене мончикитов-камптонитов присутствуют стекловатые и частично раскристаллизованные включения. Клинопироксен - хозяин отвечает диопсиду и авгиту (табл. 2, ан. 4, 5 и 6, 7, соответственно). Частично раскристаллизованные включения состоят из стекла, бурых и бесцветных дочерних фаз и газового пузырька. Бурые дочерние фазы включений в авгите представлены амфиболом, а в диопсиде - биотитом. Амфибол по составу отвечает керсутиту, содержит 4.7 мас.\% $\mathrm{TiO}_{2}$ и 0.16 мас.\% ВаО. В биотите также отмечается высокое (3.45 мас. \%) содержание $\mathrm{TiO}_{2}$ (табл. 2, ан. 9 и 11, соответственно). Размягчение стекла включений происходит при $730-760^{\circ} \mathrm{C}$, подплавление бесцветных дочерних фаз около $800^{\circ} \mathrm{C}$, бурых фаз - при $830^{\circ} \mathrm{C}$. Интенсивное плавление дочерних фаз включений осуществляется при $1000-1100^{\circ} \mathrm{C}$. При этих температурах очень часто происходит разгерметизация включений. Гомогенизировать удалось лишь очень мелкие включения при $1210-1255^{\circ} \mathrm{C}$.

Стекловатые включения в клинопироксене мончикитов иногда содержат темную полость с жидкой и газообразной $\mathrm{CO}_{2}$. Во время охлаждения жидкая $\mathrm{CO}_{2}$ кристаллизуется метастабильно при $-100,-102^{\circ} \mathrm{C}$, а ее плавление наблюдается при нагревании до $-56.6{ }^{\circ} \mathrm{C}$. Гомогенизация углекислоты происходит при $+24^{\circ} \mathrm{C}$ в жидкость, плотность которой

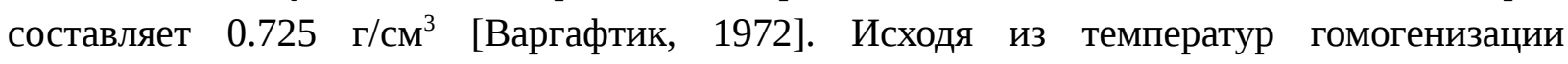
стекловатых включений, которые соответствуют $1200-1215^{\circ} \mathrm{C}$, давление расплава в момент его захвата пироксеном соответствовало 4.58 кбар [Шмонов, Шмулович, 1975; Томиленко и др., 1977].

Поскольку большинство включений вскрывается при нагревании и прогомогенизировать удается лишь очень мелкие включения, нами в минералах мончикитов-камптонитов были химически проанализированы непрогретые стекловатые включения (табл. 3, ан. 12) и остаточные стекла в частично раскристаллизованных включениях (табл. 3, ан. 13-15). Их химический состав отражает состав дифференциатов, оставшихся после частичной кристаллизации захваченного расплава в замкнутой вакуоли. Согласно анализу, стекло имеет $\mathrm{K}-\mathrm{Na}$ фонолитовый состав, в котором количество $\mathrm{Al}_{2} \mathrm{O}_{3}$ достигает 20-22 мас.\%, а щелочей - 10-11 мас. \% при незначительном преобладании К над $\mathrm{Na}$. Этот состав довольно близок промежуточному составу фойяитов-итсидритов Сыннырского массива (табл. 1 , ан. 4, 5).

В мончикитах силикатные включения были обнаружены также в амфиболекерсутите (табл. 2, ан. 8). Включения единичные, форма их округлая, частично ограненная, содержимое - стекловатое и частично раскристаллизованное. В стекловатых включениях обычно присутствует газовый пузырек, который при $700-750^{\circ} \mathrm{C}$ начинает увеличиваться, при $1100^{\circ} \mathrm{C}$ достигает максимальных размеров, а затем начинает уменьшаться. При $1180^{\circ} \mathrm{C}$ включения становятся темными и взрываются. Химический 
состав остаточных стекол непрогретых частично раскристаллизованных включений также отвечает K-Na фонолиту, содержит до 0.6 мас.\% $\mathrm{P}_{2} \mathrm{O}_{5}$ (табл. 3, ан. 16).

Следовательно, состав остаточных стекол в частично раскристаллизованных включениях, присутствующих в клинопироксене и амфиболе мончикитов-камптонитов, оказался достаточно близок, как это и было ранее установлено в щелочных базальтоидах из разных регионов мира [Панина, 1983], к составу высокоглиноземистых высококалиевых пород типа сынныритов и близким к ним по химизму нефелиновым сиенитам Сыннырского плутона.

\section{Хроматографические исследования}

С помощью хроматографического анализа нами были изучены сынныриты и получены данные о составе флюидов при их формировании на определенных температурных отрезках, начиная с $1000^{\circ} \mathrm{C}$. Как показал анализ (табл. 4), состав флюидов был простой и включал ограниченное количество газов - $\mathrm{CO}_{2}, \mathrm{CO}, \mathrm{H}_{2} \mathrm{O}$. В очень незначительном количестве присутствовали также $\mathrm{N}_{2}, \mathrm{CH}_{4}$, углеводороды. Наиболее высокое количество флюидов присутствовало при 920-890 $\mathrm{C}$. Среди летучих компонентов отмечалось: 4051.0-1751.8 мг/кг $\mathrm{CO}_{2}$, 643.6-377.0 мг/кг $\mathrm{H}_{2} \mathrm{O}$ и 83.7-42.7 мг/кг СО. При понижении температуры количество флюидов резко уменьшилось, особенно $\mathrm{CO}_{2}$, и вода начала преобладать над углекислотой. Резкое падение количества $\mathrm{CO}_{2}$, по всей видимости, было связано с проявлением карбонатно-силикатной жидкостной несмесимости, которая была обусловлена накоплением в силикатном расплаве большого количества углекислоты и других летучих компонентов. Проявление жидкостной карбонатно-силикатной несмесимости при формировании сыннырских пород детально рассмотрено в работе Л.И. Паниной и Л.И. Усольцевой [2003]. Об этом косвенно также свидетельствует присутствие в минералах изучаемых пород карбонатно-солевых включений.Для щелочных магм, как показало изучение расплавных включений в минералах разных пород [Панина, Усольцева, 1999; Соловова и др., 1996; Nielsen et al., 1997], проявление карбонатно-силикатной несмесимости является характерной особенностью. Более необычным для щелочных силикатных расплавов явилось присутствие на высокотемпературном магматическом этапе воды. Роль воды и ее количества при образовании ультракалиевых высокоглиноземистых расплавов, ответственных за формирование сынныритов, будут рассмотрены ниже.

\section{Обсуждение}

Изучение расплавных включений показало, что на Сыннырском массиве клинопироксен в шонкинитах кристаллизовался при $1280-1235^{\circ} \mathrm{C}$, калиевый полевой шпат в псевдолейцитовых сиенитах - при $1200-1180^{\circ} \mathrm{C}$, апатит из шлиров в шонкинитах, гнезд в слюдистых пироксенитах и сынныритах - около $1180-1050^{\circ} \mathrm{C}$. Аналогичные температуры кристаллизации одноименных минералов были ранее установлены в некоторых породах Сыннырского и других ультракалиевых массивов [Костюк и др., 1990; Панина и др., 1990]. Так, кристаллизация клинопироксена в слюдистых пироксенитах и дитроитах Сыннырского массива отмечалась при $1280-1190^{\circ} \mathrm{C}$ и $1210-1150^{\circ} \mathrm{C}$, соответственно; в пироксенитах и шонкинитах Сакунского массива - при $1310-1280^{\circ} \mathrm{C}$ и $1280-1260^{\circ} \mathrm{C}$, соответственно; пироксенитах Маломурунского массива - при $1280-1210^{\circ} \mathrm{C}$. Кристаллизация апатита, присутствовавшего в пироксенитах Сакунского и Маломурунского массивов, происходила при $1240-1200^{\circ} \mathrm{C}$ и $1200^{\circ} \mathrm{C}$, соответственно [Панина и др., 1991]. Кроме того, на Маломурунском массиве были также зафиксированы 
температуры $\left(1360-1290^{\circ} \mathrm{C}\right)$ кристаллизации оливина в пироксен-мелилит-оливиновых породах [Панина и др., 1989], а на Сыннырском плутоне - температуры образования лейцита $\left(1250-1200^{\circ} \mathrm{C}\right)$ и нефелина в псевдолейцитовых и нефелиновых сиенитах (1100$880^{\circ} \mathrm{C}$ ) [Панина, 1978]. Следовательно, можно сделать вывод, что независимо от состава породы в рассматриваемых массивах одноименные минералы кристаллизовались при близких температурах по схеме: оливин $\rightarrow$ клинопироксен $\leftrightarrow$ лейцит $\rightarrow$ калиевый полевой шпат $\leftrightarrow$ апатит $\rightarrow$ нефелин. Это свидетельствует о кристаллизации всех пород ультракалиевых массивов из материнской магмы одного состава в процессе ее эволюционного преобразования.

Было также установлено, что клинопироксен в мончикитах-камптонитах кристаллизовался при $1255-1210^{\circ} \mathrm{C}$ и давления 4.58 кбар, т.е. кристаллизовался практически при тех же температурах, что и клинопироксен в шонкинитах. Близкие температуры кристаллизации одноименных минералов и аналогичный порядок их выделения был ранее установлен также для щелочных базальтоидов из разных регионов мира. Так, согласно данным [Поляков и др., 1985; Костюк и др., 1990], образование минералов в калиевых щелочных базальтоидах обычно происходит в следующей последовательности: оливин $\quad\left(\geq 1400-1280^{\circ} \mathrm{C}\right) \rightarrow$ клинопироксен $\quad\left(1380-1180^{\circ} \mathrm{C}\right) \leftrightarrow$ лейцит $\left(1350-1150^{\circ} \mathrm{C}\right) \rightarrow$ плагиоклаз $\left(1220-1180^{\circ} \mathrm{C}\right) \rightarrow$ биотит $\leftrightarrow$ апатит $\left(1240-1200^{\circ} \mathrm{C}\right)$.

По полученным данным, кристаллизация минералов при формировании пород Сыннырского массива сопровождалась уменьшением в расплаве $\mathrm{Fe}, \mathrm{Mg}$, Са и увеличением $\mathrm{Si}, \mathrm{Al}$, K. Было установлено, что в процессе кристаллизации клинопироксена в шонкинитах расплавы имели мелафонолитовый состав (табл. 3, ан. 1-3). При этом отметим, что на Сакунском массиве кристаллизация клинопироксена в более ранних слюдистых пироксенитах осуществлялась из более основного тефритового расплава [Костюк и др., 1990]. Образование калиевого полевого шпата в сыннырских псевдолейцитовых сиенитах происходило из калиевых фонолитовых расплавов (табл. 3, ан. 4). При кристаллизации апатита расплавы становились все более отдифференцированными, все более высокоглиноземистыми, ультракалиевыми, все более близкими к составам псевдолейцитовых сиенитов и сынныритов (табл. 3, ан. 5-11). Расплавы, отвечающие составам сынныритов, сформировались при температурах, незначительно превышающих $1050-1180^{\circ} \mathrm{C}$, на завершающих стадиях преобразования материнской магмы. Это были первые прямые доказательства образования сынныритов из магматических расплавов на завершающих стадиях кристаллизации материнской магмы и первые прямые данные о составах и особенностях преобразования высокоглиноземистых калиевых расплавов в процессе формирования сынныритов.

Согласно [Костюк и др., 1990; Cioni et al., 1998; Панина и др., 1990; Lima, 2000; Kamenetsky et al., 1995; Исакова и др., 2019] преобразование щелочнобазальтоидных магм в законсервированных включениях также осуществляется в направлении тефритовых, мелафонолитовых и фонолитовых расплавов. Проанализированные нами остаточные стекла в частично раскристаллизованных включениях в клинопироксене и амфиболе мончикитов-камптонитов имеют фонолитовый состав (табл. 3, ан. 12-16).

Близкие температуры кристаллизации одноименных минералов, выделявшихся в одной и той же последовательности, а также близость составов отдифференцированных фракций кристаллизовавшихся расплавов при формировании пород Сыннырского массива 
и остаточных стекол включений в минералах щелочных базальтоидов подтвердили ранее сделанный вывод об аналогичности состава их материнских магм.

Исходя из установленного порядка образования минералов, мы попытались проследить тренд эволюции материнской магмы в процессе ее кристаллизации и формирования пород Сыннырского массива (рис. 2, табл. 3). На рисунке отчетливо видно, что при последовательной кристаллизации минералов в магме уменьшалось содержание $\mathrm{FeO}, \mathrm{MgO}, \mathrm{CaO}$ и увеличивалось количество $\mathrm{SiO}_{2}, \mathrm{Al}_{2} \mathrm{O}_{3}$ и $\mathrm{K}_{2} \mathrm{O}$, образуя единый тренд эволюции. Подобный тренд ещё раз подтверждает, что все рассматриваемые породы кристаллизовались из единой родоначальной магмы в процессе ее дифференциации и фракционирования. Исходя из предполагаемого щелочнобазальтоидного ее состава, на этот же тренд преобразования мы попытались разместить составы остаточных расплавов, законсервированных в минералах мончикитов-камптонитов, чтобы убедиться в их сопоставимости и однонаправленном преобразовании в ходе кристаллизации. Выяснилось (рис. 2), что остаточные расплавы не только не искажают тренд преобразования материнской магмы, но даже несколько дополняют его. Это явилось веским подтверждением того, что материнская магма, ответственная за формирование пород Сыннырского массива, имела щелочнобазитовый состав, а образование сынныритов связано с длительным ее преобразованием в закрытых условиях (на подобие макровакуолей включений), исключающих потерю летучих компонентов.

Данный вывод подтверждается и расположением полученных результатов на диаграмме $\mathrm{Al}_{2} \mathrm{O}_{3}-\mathrm{FeO}-\mathrm{K}_{2} \mathrm{O}$ (рис. 3), отражающей положение состава щелочных базальтоидов и их остаточных стекол из включений в минералах [Панина, 1983]. На диаграмме составы малодифференцированных расплавов из включений в клинопироксене шонкинитов (А, Б, В, соответствующие табл. 3, ан. 1-3), располагаются в I поле щелочных базитов. Несколько более отдифференцированные расплавы $(\Gamma)$, законсервированные в стекловатых включениях в клинопироксене мончикитов-камптонитов (табл. 3, ан. 12), попадают в зону между полями базальтоидов и остаточных стекол включений. Состав остаточных стекол из включений в клинопироксене и амфиболе мончикитов-камптонитов (табл. 3, ан. 13-16), совместно с расплавами, законсервированными в калиевом полевом шпате псевдолейцитовых сиенитов и апатите из обособлений (табл. 3, ан. 4-11), размещаются во II поле остаточных стекол включений, содержащихся в минералах щелочных базальтоидов (на диаграмме отмечены крестиками).

О формировании сынныритоносных массивов в закрытых системах, исключающих потерю летучих и способствующих их накоплению в процессе кристаллизации материнской щелочнобазальтоидной магмы, свидетельствуют результаты проведенных нами хроматографических исследований сынныритов. Было установлено, что на завершающих стадиях формирования ультракалиевых массивов при 920-890 $\mathrm{C}$ в расплавах содержалось до 1752-4051 мг/кг $\mathrm{CO}_{2}$, 42.7-83.7 мг/кг СО и 377-644 мг/кг $\mathrm{H}_{2} \mathrm{O}$. Такое количество летучих компонентов, особенно $\mathrm{H}_{2} \mathrm{O}$ в несколько раз превышающее таковое в щелочнобазальтоидных магмах [Поляков и др., 1974; 1985], существенно повлияло на тренд дальнейшего преобразования кристаллизовавшихся расплавов.

При кристаллизации плутонических пород в закрытых условиях возросшее давление воды, согласно экспериментам Г. Йодера и К. Тилли [1965], способствовало увеличению в расплаве количества Al, препятствовало кристаллизации плагиоклаза, вместо которого образовался калиевый полевой шпат. Повышающее давление воды, кроме 
того по данным экспериментального изучения системы $\mathrm{K}_{2} \mathrm{O}-\mathrm{Na}_{2} \mathrm{O}-\mathrm{SiO}_{2}$ [Scarfe et al., 1966], сужало также поле образования лейцита, увеличивая количество $\mathrm{K}_{2} \mathrm{O}$ в расплавах. При $\mathrm{P}_{\mathrm{H} 2 \mathrm{O}}=8.4$ кбар, вместо лейцита осуществлялась совместная кристаллизация кальсилита и калиевого полевого шпата - главных компонентов сынныритов.При кристаллизации щелочных базальтоидов из-за потери летучих компонентов в связи с открытостью магматической системы эволюция магмы обычно продолжается в направлении значительного обогащения остаточных расплавов Si и понижения количества $\mathrm{Mg}$, Fe, Ca, щелочей. Из расплавов кристаллизуется плагиоклаз, а преобразование магмы, чаще всего, ограничивается трахитовым барьером.

Одной из причин редкой встречаемости в природе сынныритов является преимущественная кристаллизация щелочнобазальтоидных магм в той или иной мере открытых системах, способствующих отделению от расплава флюидов, содержащих некоторое количество воды. В редких случаях в природе появляются условия, близкие к закрытым системам, когда флюиды при кристаллизации накапливаются, а процессы дифференциации и фракционирования расплавов протекают до конца, как в микровключениях с обогащением остаточных расплавов $\mathrm{Al}$ и $\mathrm{K}$. Лишь в этих исключительных случаях конечные продукты преобразования калиевой базальтоидной магмы могут приобрести состав, близкий к составу сынныритов.

Исходя из полученных и ранее опубликованных данных, образование ультракалиевых сынныритоносных массивов можно представить следующим образом. Все породы ультракалиевых массивов были сформированы из щелочнобазальтоидных магм в процессе внутрикамерной дифференциации и фракционирования в закрытых условиях, исключающих потерю летучих компонентов. Кристаллизация каждой минеральной фазы приводила к изменению химического состава оставшихся порций материнского расплава, который эволюционировал в сторону увеличения $\mathrm{Si}, \mathrm{Al}, \mathrm{K}$ и уменьшения $\mathrm{Mg}, \mathrm{Fe}, \mathrm{Ca}-$ от тефритовых к мелафонолитовым и фонолитовым составам. Благодаря закрытости системы, кристаллизовавшиеся расплавы обогащались флюидами. Высокое давление воды препятствовало образованию плагиоклаза, способствовало накоплению глинозема, щелочей и кристаллизации калиевого полевого шпата. Спокойная тектоническая обстановка в течении длительного времени позволила минералам выкристаллизоваться и разделиться в соответствии с их удельным весом. В результате тяжелые минералы оливин, клинопироксен, апатит и рудные - опустились на дно магматической камеры, формируя нижние мезо-, мелакратовые породные серии из кумулятивных пластов и линз пироксенитов и шонкинитов, содержавших апатитовые обособления. После отсадки тяжелых минералов из отдифференцированных расплавов, скопившихся на верхних горизонтах магматической камеры, была сформирована верхняя лейкократовая серия пород. Продолжавшееся эволюционное преобразование в закрытых условиях способствовало дальнейшему увеличению $\mathrm{Al}$ и $\mathrm{K}$ и приобретению остаточными расплавами ультракалиевого высокоглиноземистого состава, из которого кристаллизовались сынныриты. Высокое давление воды в магматической камере обусловило совместную кристаллизацию кальсилита и калиевого полевого шпата вместо лейцита. 


\section{Выводы}

1. Весь гомодромный ряд пород ультракалиевых сынныритоносных массивов формировался из единой щелочнобазальтовой магмы калиевого типа щелочности в процессе длительной дифференциации и фракционитования в закрытых условиях, исключающих отход воды и других летучих компонентов.

2. Кристаллизация магмы, как и при формировании вулканитов, начиналась с выделения фемических минералов при близких (около $1300^{\circ} \mathrm{C}$ ) температурах, в той же последовательности с увеличением в отдифференцированных расплавах $\mathrm{Si}, \mathrm{Al}, \mathrm{K}$ и уменьшением $\mathrm{Mg}$, Fe, Са при эволюции в сторону тефритовых, мелафонолитовых фонолитовых составов.

3. В процессе фракционирования тяжелые минералы опускались на дно магматической камеры, образуя нижнюю мезо-, меланократовую породную серию, а из всплывших отдифференцированных расплавов формировалась верхняя лейкократовая серия пород.

4. Возрастающее в процессе кристаллизации магмы количество воды и других флюидов препятствовало кристаллизации плагиоклаза и способствовало дальнейшему увеличению в расплаве $\mathrm{Al}$ и $\mathrm{K}$, вплоть до образования на завершающих стадиях преобразования (около $1180-1050^{\circ} \mathrm{C}$ ) высокоглиноземистых ультракалиевых остаточных расплавов, из которых формировались сынныриты.

Благодарности. Авторы благодарны И.А. Андреевой за обсуждение статьи и сделанные замечания.

Работа выполнена в рамках Государственного задания (проект № 330-2016-005) при финансовой поддержке РФФИ (проект № 17-05-00285a). 
Андреев Г.В. Петрология Сыннырского щелочного массива. Улан-Удэ, 1965, 117 с.

Андреева Е.Д., Кононова В.А., Свешникова Е.В., Яшина Р.М. Магматическая горные породы. Щелочные породы. М.; Наука, т. 2, 1984, 416 с.

Архангельская В.В. Редкометальные щелочные комплексы южного края Сибирской платформы. М.; Недра, 1974, 128 с.

Базарова Т.Ю., Костюк В.П., Хмельникова О.А. Особенности формирования щелочных базальтов Большого Анюя (приток Колымы) // Докл. АН СССР, 1981, т. 259, № 5, с. 11921194.

Варгафтик Н.Б. Справочник по теплофизическим свойствам газов и жидкостей. М.; Наука, 1972, 720 c.

Горстка В.Н., Крапивин А.Г. Жильные образования. В кн. Геологическое строение и апатитоносность Сыннырского щелочного массива. Ленинград, Наука, 1969, 147 с.

Жидков А.Я. Типизация и распределение калийно-глиноземистых руд в Сыннырском щелочном массиве // Докл. АН СССР, 1978, т. 242, № 5, с. 1140-1143.

Жидков А.Я. Ультракалиевая салическая ветвь интрузивных щелочных пород. В кн. Петрология. М.; Наука, 1980, с. 81-95.

Жидков А.Я. Сынныриты - новое комплексное сырье // Природа, 1986, № 5, с. 96-101.

Исакова А.Т., Панина Л.И., Стоппа Ф. Условия образования лейцит-содержащих магм комплекса Больсена (Вульсини, Италия): по результатам изучения расплавных включений в минералах // Геология и геофизика, 2019, т. 60, №2, с. 143-158.

Йодер Г.С., Тилли К.Э. Происхождение базальтовых магм. М.: Мир, 1965, 246 с.

Костюк В.П. Калиевый щелочной магматизм Байкало-Алданского пояса // Геология и геофизика, 1983, № 5, с. 33-42.

Костюк В.П. Байкало-Становая рифтогенная структура и место щелочного магматизма в ней // Геология и геофизика, 1990, №4, с. 28-35.

Костюк В.П., Базарова Т.Ю., Панина Л.И., Вавилов М.А. О дифференциации щелочных базальтоидных магм и возможности образования высококалиевых природных расплавов // Геология и геофизика, 1986, № 2, с. 79-85.

Костюк В.П., Панина Л.И., Жидков А.Я., Орлова М.П., Базарова Т.Ю. Калиевый щелочной магматизм Байкало-Становой рифтогенной системы. Новосибирск, Наука, 1990, 234 с.

Орлова М.П., Жидков А.Я., Орлов Д.М., Зотова И.Ф. Внутренняя структура и формирование Сыннырского щелочного массива (Северное Прибайкалье) // Геохимия, 1993, №8, с. 1161-1181.

Панина Л.И. О температурах кристаллизации пироксена и лейцита в щелочных породах Сыннырского плутона // Геология и геофизика, 1978, №6, с. 54-60.

Панина Л.И. Образование высококалиевых богатых глиноземом расплавов // Геология и геофизика, 1983, № 4, с.34-40.

Панина Л.И., Моторина И.В., Шарыгин В.В., Владыкин Н.В. Биотитовые пироксениты и мелилит-монтичеллит-оливиновые породы Мало-Мурунского щелочного массива и их генезис (Якутия) // Геология и геофизика, 1989, Т.4, № 12, с. 41-57.

Панина Л.И., Шарыгин В.В., Моторина И.В. Слюдяные пироксениты как продукты ранних этапов эволюции калиевой щелочной магмы (на примере Маломурунского массива (Алданский щит) // Геология и геофизика, 1990, №3, с. 71-78. 
Панина Л.И., Шарыгин В.В., Прошенкин И.Е. Апатитоносность калиевых щелочных массивов // Геология и геофизика, 1991, №1, с. 107-115.

Панина Л.И., Усольцева Л.М. Роль жидкостной несмесимости в образовании кальцитовых карбонатитов Маломурунского массива (Алдан) // Петрология, 1999, т. 7, № 6, с. 653-669. Панина Л.И., Усольцева Л.М. Проблема карбонатитообразования на Сыннырском щелочном массиве (Северное Прибайкалье). В сб. Плюмы и глубинные источники щелочного магматизма. Материалы III Международного семинара, 2003, Хабаровск, с. 7587.

Поляков А.И., Наумов В.Б., Романчев В.П. Условия формирования пород по данным термометрических исследований. В кн. Восточно-Африканская рифтовая система. М., Наука, 1974, т. 3, с. 179-183.

Поляков А.И., Турков В.А., Муравьева Н.С., Несмеянова Л.И., Игнатенко К.И. Физикохимические условия процессов выплавления и эволюции базальтовых магм Байкальской рифтовой зоны // Геохимия, 1985, №1, с. 41-58.

Салоп Л.И. Геология Байкальской горной области. М., Недра, 1967, Т.2, 699 с.

Соловова И.П., Гирнис А.В., Рябчиков И.Д. Включения карбонатных и силикатных расплавов в минералах щелочных базальтоидов Восточного Памира // Петрология, 1996, T.4, №4, с. 339-363.

Томиленко А.А., Бердников Н.В., Карсаков Л.П. Криометрия включений в породах Чогарского глубинного метаморфического комплекса (Восточная Сибирь) // Докл. АН СССР, 1977, т. 234, № 5, с. 1189-1192.

Чепуров А.И., Базарова Т.Ю., Лаврентьев Ю.Г., Покачалова О.С. Состав включений магматического расплава в минералах фергусит-порфира (Восточный Памир) и псевдолейцититах (Центральный Алдан) // Докл. АН СССР, 1974, т. 218, №5, с. 1185-1188.

Шарыгин В.В., Панина Л.И. Меланократовые породы участка Калюмный (Сыннырский массив) // Геология и геофизика, 1993, т. 34, № 8, с. 109-116.

Шмонов В.М., Шмулович К.И. Мольные объемы и уравнения состояния $\mathrm{CO}_{2}$ в интервале 100-1000ㄷ и 2000-10000 бар // Докл. АН СССР, 1975, т. 217, №4, с. 935-938.

Яшина Р.М. Щелочной магматизм складчато-глыбовых областей. М., Наука, 1982, 273 с.

Bea F., Montero P., Haissen F., Rjimati E., Molina J.F., Scarrow J.H. Kalsilite-bearing plutonic rock: The deep-seated Archead Awsard massif of the Reguibat Rise, South Morocco, West African craton // Earth-Science Reviews, 2014, № 138, p. 1-24.

Brooks C.K., Fawcett J.J., Gittins J., Rucklidge J.C. The Batbjerg complex, east Greenlandia unique ultrapotassic Caledonian intrusion // Can. J. Earth Sci, 1981, № 18, p.274-285.

Cioni R., Marianelli P., Santacrose R. Thermal and compositional evolution of the shallow magma chambers of Vesuvius: Evidence from pyroxene phenocrysts and melt inclusions // J. Geophys Res., 1998, v. 103, № 138, p. 18277-18294.

Lima A. Experimental study on silicate-melt inclusions in clinopyroxene phenocrists from Roccamonfina lava (Italy) // Mineral. Petrol., 2000, v. 70, p. 199-220.

Kamenetsky V., Metrich N., Cioni R. Potassic primary melts of Vulsini (Roman Province): evidence from mineralogy and melt inclusions // Contr. Miner. Petrol., 1995, v. 120, p. 186-196.

Nielsen T.F.D., Solovova I.P., Veksler I.V. Parental melts of melilitolite and origin of alkaline carbonatite: evidence from crystallized melt inclusions, Cardiner Complex // Contr. Miner. Petrol.., 1997, V. 126, p. 331-344. 
Scarfe C.M., Luth W.C., Tuttle O.F. An experimental study bearing on the absence of leucite in the plutonic rocks // Amer. Mineral., 1966, V.51, p. 726-735. 
Рис. 1. Строение Сыннырского массива (Костюк и др., 1990). 1 - пуласкиты и гедрумиты второй интрузивной фазы; 2-4 - нефелин-кальсилитовые сиениты первой интрузивной фазы: 2 - сынныриты внутренней зоны, 3 - сынныриты переходной зоны, 4 - нефелиновые сиениты, фойяиты, порфировые псевдолейцитовые сиениты внешней зоны; 5 - гранитоиды витимканского комплекса; 6 - известняки кооктинской свиты; 7 песчаники, алевролиты и конгломераты холоднинской свиты; 8 - эффузивы основного и 9 - среднего состава сыннырской свиты; 10 - элементы залегания.

Рис. 2. Эволюционное преобразование материнской магмы при формировании пород Сыннырского массива. Состав законсервированных расплавов: 1-3 - в клинопироксене шонкинитов (табл. 3, ан. 1-3); 4-7 - в клинопироксене мончикитовкамптонитов (табл. 3, ан. 12-15); 8 - в амфиболе мончикитов (табл. 3, ан. 16); 9 - в калишпате псевдолейцитовых сиенитов (табл. 3, ан. 4); 10-16 - в апатите из апатитовых обособлений в пироксенитах, шонкинитах, сынныритах (табл. 3; ан. 5-11).

Рис. 3. Положение составов щелочных базальтоидов (I), их остаточных стекол (II) и законсервированных расплавов в минералах сыннырских пород в системе $\mathrm{Al}_{2} \mathrm{O}_{3}$ $\mathrm{FeO}-\mathrm{K}_{2} \mathrm{O}$.

1 - пиролит (Горячегорский массив), 2 - щелочной базальт (Большой Анюй), 3 оливиновый трахибазальт, 4 - анальцимовый тефрит и 5 - анальцимовый базальт (Ю. Армения), 6 - фергусит-порфир (В.Памир), 7 - оливиновый псевдолейцитит (Ц. Алдан); а - нефелиновый сиенит и б - сыннырит Сыннырского массива, в - сыннырит Сакунского массива. Расплавные включения в минералах сыннырских пород: А, Б, В - в клинопироксене шонкинитов, Г - стекловатые включения в клинопироксене мончикитов-камптонитов. Крестиком отмечены включения в калиевом полевом шпате псевдолейцитовых сиенитов, апатите из обособлений в сынныритах, пироксенитах и шонкинитах, а также остаточные стекла из включений в клинопироксене и амфиболе мончикитов-камптонитов. 
Табл. 1 Химический состав пород Сыннырского массива, мас. \%

\begin{tabular}{l|l|l|l|l|l|l|l|l|l|l|l|l|l}
\hline $\begin{array}{l}\mathrm{N}, \\
\mathrm{N}\end{array}$ & порода & $\mathrm{SiO}_{2}$ & $\mathrm{TiO}_{2}$ & $\mathrm{Al}_{2} \mathrm{O}_{3}$ & $\mathrm{FeO}$ & $\mathrm{MnO}$ & $\mathrm{MgO}$ & $\mathrm{CaO}$ & $\mathrm{Na}_{2} \mathrm{O}$ & $\mathrm{K}_{2} \mathrm{O}$ & $\mathrm{P}_{2} \mathrm{O}_{5}$ & $\mathrm{BaO}$ & Сумма \\
\hline 1 & $\begin{array}{l}\text { слюдистые } \\
\text { пироксениты }\end{array}$ & 43.49 & 1.88 & 9.28 & 15.01 & 0.30 & 9.20 & 12.60 & 0.81 & 3.65 & 1.30 & 0.41 & 97.93 \\
\hline 2 & шонкиниты & 50.00 & 0.95 & 12.00 & 10.05 & 0.23 & 7.00 & 9.50 & 1.50 & 7.00 & 0.55 & 0.00 & 98.78 \\
\hline 3 & пуласкиты & 55.43 & 0.98 & 15.02 & 7.07 & 0.12 & 2.95 & 4.98 & 3.25 & 7.32 & 0.29 & 0.72 & 98.43 \\
\hline 4 & фойяиты & 54.50 & 1.20 & 17.50 & 8.75 & 0.11 & 0.25 & 5.00 & 4.50 & 6.00 & 0.23 & 0.00 & 98.04 \\
\hline 5 & итсиндриты & 55.58 & 0.50 & 22.13 & 2.73 & 0.04 & 0.59 & 0.91 & 5.89 & 10.12 & 0.07 & 0.00 & 98.66 \\
\hline 6 & диориты & 55.43 & 0.30 & 22.11 & 1.23 & 0.02 & 0.50 & 1.02 & 2.65 & 13.57 & 0.15 & 0.00 & 99.89 \\
\hline 7 & $\begin{array}{l}\text { псевдолейцитовые } \\
\text { сиениты }\end{array}$ & 54.92 & 0.14 & 22.89 & 1.82 & 0.01 & 0.21 & 0.62 & 1.27 & 16.52 & 0.07 & 0.03 & 98.50 \\
\hline 8 & сынныриты & 54.82 & 0.16 & 22.52 & 1.57 & 0.01 & 0.58 & 0.72 & 1.57 & 16.50 & 0.06 & 0.17 & 98.68 \\
\hline 9 & сынныриты & 54.88 & 0.05 & 23.20 & 1.02 & 0.02 & 0.24 & 0.27 & 0.72 & 18.38 & 0.03 & 0.00 & 98.81 \\
\hline
\end{tabular}

Примечание: * в том числе (мас. \%): N3 - 0.35 F, N5 - 0.19 F, N7 - 0.24 F. 
Таблица 2. Химический состав клинопироксена, амфибола, биотита, калиевого полевого шпата, апатита, мас. \%

\begin{tabular}{|c|c|c|c|c|c|c|c|c|c|c|c|c|c|c|c|}
\hline \multirow[t]{2}{*}{ окислы } & \multicolumn{7}{|c|}{ клинопироксен } & \multicolumn{2}{|c|}{ амфибол } & \multicolumn{2}{|c|}{ биотит } & \multirow{2}{*}{$\begin{array}{c}\begin{array}{c}\text { калиевый } \\
\text { полевой } \\
\text { шпат }\end{array} \\
12 \\
\end{array}$} & \multicolumn{3}{|c|}{ апатит } \\
\hline & 1 & 2 & 3 & 4 & 5 & 6 & 7 & 8 & 9 & 10 & 11 & & 13 & 14 & 15 \\
\hline $\mathrm{SiO}_{2}$ & $\begin{array}{c}50.0 \\
7 \\
\end{array}$ & $\begin{array}{c}50.3 \\
2 \\
\end{array}$ & 51.66 & $\begin{array}{c}53.7 \\
4 \\
\end{array}$ & $\begin{array}{c}54.9 \\
4 \\
\end{array}$ & $\begin{array}{c}45.8 \\
9 \\
\end{array}$ & $\begin{array}{c}46.8 \\
5 \\
\end{array}$ & $\begin{array}{c}38.6 \\
3 \\
\end{array}$ & $\begin{array}{c}38.3 \\
4 \\
\end{array}$ & $\begin{array}{c}35.3 \\
3 \\
\end{array}$ & $\begin{array}{c}36.2 \\
5 \\
\end{array}$ & 63.50 & 0.00 & 0.00 & 0.00 \\
\hline $\mathrm{TiO}_{2}$ & 0.64 & 0.53 & 0.31 & 0.08 & 0.12 & 3.03 & 2.35 & 5.94 & 4.71 & 2.94 & 3.45 & 0.08 & 0.00 & 0.00 & 0.00 \\
\hline $\mathrm{Al}_{2} \mathrm{O}_{3}$ & 2.65 & 2.45 & 3.93 & 0.68 & 0.70 & 8.65 & 5.80 & $\begin{array}{c}13.4 \\
6\end{array}$ & $\begin{array}{c}14.5 \\
0\end{array}$ & $\begin{array}{c}13.8 \\
1\end{array}$ & $\begin{array}{c}16.6 \\
3\end{array}$ & 19.50 & 0.00 & 0.00 & 0.00 \\
\hline $\mathrm{FeO}$ & $\begin{array}{c}14.9 \\
2 \\
\end{array}$ & $\begin{array}{c}13.2 \\
2 \\
\end{array}$ & 13.10 & 4.51 & 4.51 & 7.58 & 7.41 & $\begin{array}{c}11.8 \\
8 \\
\end{array}$ & $\begin{array}{c}13.2 \\
7 \\
\end{array}$ & $\begin{array}{c}21.6 \\
0 \\
\end{array}$ & $\begin{array}{c}18.9 \\
3 \\
\end{array}$ & 0.03 & 0.00 & 0.00 & 0.00 \\
\hline $\mathrm{MnO}$ & 0.01 & 0.00 & 0.00 & 0.00 & 0.00 & 0.00 & 0.01 & 0.00 & 0.00 & 0.01 & 0.00 & 0.00 & 0.00 & 0.00 & 0.00 \\
\hline $\mathrm{MgO}$ & 8.69 & 9.82 & 9.14 & $\begin{array}{c}16.4 \\
2\end{array}$ & $\begin{array}{c}16.0 \\
3 \\
\end{array}$ & $\begin{array}{c}12.2 \\
3\end{array}$ & $\begin{array}{c}13.7 \\
7\end{array}$ & $\begin{array}{c}11.7 \\
2\end{array}$ & $\begin{array}{c}10.2 \\
3 \\
\end{array}$ & $\begin{array}{c}11.1 \\
9\end{array}$ & $\begin{array}{c}10.2 \\
1\end{array}$ & 0.00 & 0.00 & 0.00 & 0.00 \\
\hline $\mathrm{CaO}$ & $\begin{array}{c}20.4 \\
6 \\
\end{array}$ & $\begin{array}{c}21.8 \\
9 \\
\end{array}$ & 20.05 & $\begin{array}{c}22.7 \\
8 \\
\end{array}$ & $\begin{array}{c}22.5 \\
6 \\
\end{array}$ & $\begin{array}{c}21.7 \\
8 \\
\end{array}$ & $\begin{array}{c}21.9 \\
9 \\
\end{array}$ & $\begin{array}{c}11.6 \\
7 \\
\end{array}$ & $\begin{array}{c}11.8 \\
8 \\
\end{array}$ & 0.63 & 0.73 & 0.01 & 53.51 & 54.26 & 53.42 \\
\hline $\mathrm{Na}_{2} \mathrm{O}$ & 2.35 & 1.64 & 2.94 & 0.39 & 0.40 & 0.62 & 0.53 & 2.40 & 2.57 & 0.15 & 0.96 & 0.50 & 0.19 & 0.23 & 0.22 \\
\hline $\mathrm{K}_{2} \mathrm{O}$ & 0.01 & 0.01 & 0.01 & 0.00 & 0.00 & 0.01 & 0.00 & 1.53 & 1.50 & 9.17 & 7.88 & 14.01 & 0.01 & 0.04 & 0.00 \\
\hline $\mathrm{P}_{2} \mathrm{O}_{5}$ & 0.00 & 0.00 & 0.00 & 0.00 & 0.00 & 0.00 & 0.00 & 0.00 & 0.00 & 0.00 & 0.00 & 0.00 & 39.47 & 39.93 & 38.91 \\
\hline $\mathrm{BaO}$ & 0.00 & 0.00 & 0.00 & 0.00 & 0.00 & 0.15 & 0.05 & 0.27 & 0.16 & 0.42 & 0.00 & 2.46 & 0.07 & 0.00 & 0.00 \\
\hline Сумма & $\begin{array}{c}99.9 \\
1 \\
\end{array}$ & $\begin{array}{c}99.8 \\
7\end{array}$ & $\begin{array}{c}100.1 \\
4\end{array}$ & $\begin{array}{c}98.6 \\
0\end{array}$ & $\begin{array}{c}99.2 \\
6 \\
\end{array}$ & $\begin{array}{c}99.9 \\
4\end{array}$ & $\begin{array}{c}98.7 \\
6 \\
\end{array}$ & $\begin{array}{c}97.5 \\
0 \\
\end{array}$ & $\begin{array}{c}97.1 \\
6 \\
\end{array}$ & $\begin{array}{c}95.2 \\
5\end{array}$ & $\begin{array}{c}95.0 \\
4 \\
\end{array}$ & 100.09 & 98.81* & 97.86* & 97.71* \\
\hline
\end{tabular}

Примечание: * в том числе (мас. \%): №13 - 2.56 SrO, 2.86 F; №14 - 0.49 SrO, 2.90 F; №15 - 2.17 SrO, 2.93 F.

1-8, 12-15 - минералы-хозяева включений, 9-11 - дочерние фазы включений. Породы: 1-3, 10 - шонкиниты; 4-9, 11 -

мончикиты-камптониты; 12 - псевдолейцитовые сиениты. Апатит из обособлений: 13 - в слюдистых пироксенитах, 14 - в

шонкинитах, 15 - в сынныритах. 
Таблица 3. Химический состав силикатных расплавных включений в минералах плутонических (1-11) и дайковых (12-16) пород Сыннырского массива, мас. \%

\begin{tabular}{|l|l|l|l|l|l|l|l|l|l|l|l|l|l|l|l|l|}
\hline $\mathrm{NN}$ & матрица & $\mathrm{SiO}_{2}$ & $\mathrm{TiO}_{2}$ & $\mathrm{Al}_{2} \mathrm{O}_{3}$ & $\mathrm{FeO}$ & $\mathrm{MgO}$ & $\mathrm{CaO}$ & $\mathrm{Na}_{2} \mathrm{O}$ & $\mathrm{K}_{2} \mathrm{O}$ & $\mathrm{P}_{2} \mathrm{O}_{5}$ & $\mathrm{BaO}$ & $\mathrm{SrO}$ & $\mathrm{SO}$ & $\mathrm{Cl}$ & $\mathrm{F}$ & $\mathrm{Cyммa}$ \\
\hline 1 & $\mathrm{Cpx}$ & 52.38 & 1.20 & 9.86 & 10.52 & 3.98 & 14.62 & 2.83 & 3.06 & 0.03 & 0.00 & 0.25 & 0.00 & 0.00 & 0.00 & 98.73 \\
\hline 2 & $\mathrm{Cpx}$ & 52.95 & 1.18 & 10.84 & 8.24 & 4.62 & 12.34 & 2.20 & 5.62 & 0.08 & 0.02 & 0.00 & 0.00 & 0.00 & 0.00 & 98.09 \\
\hline 3 & $\mathrm{Cpx}$ & 54.54 & 0.47 & 13.06 & 7.90 & 2.77 & 9.33 & 3.92 & 5.09 & 0.03 & 0.00 & 0.10 & 0.00 & 0.00 & 0.00 & 97.27 \\
\hline 4 & $\mathrm{Kfs}$ & 55.64 & 0.16 & 22.56 & 0.84 & 0.08 & 1.56 & 2.80 & 12.35 & 0.10 & 2.20 & 0.00 & 0.00 & 0.00 & 0.00 & 98.29 \\
\hline 5 & $\mathrm{Ap}$ & 56.69 & 0.00 & 23.16 & 0.07 & 0.00 & 2.61 & 2.09 & 13.59 & 0.23 & 0.00 & 0.00 & 0.00 & 0.00 & 0.00 & 98.44 \\
\hline 6 & $\mathrm{Ap}$ & 53.86 & 0.00 & 23.30 & 0.12 & 0.00 & 2.17 & 3.52 & 15.24 & 0.59 & 0.00 & 0.00 & 0.12 & 0.17 & 0.13 & 99.22 \\
\hline 7 & $\mathrm{Ap}$ & 54.44 & 0.00 & 23.05 & 0.16 & 0.00 & 1.28 & 3.87 & 15.04 & 0.30 & 0.06 & 0.00 & 0.00 & 0.06 & 0.04 & 98.30 \\
\hline 8 & $\mathrm{Ap}$ & 55.11 & 0.00 & 22.00 & 0.08 & 0.00 & 1.12 & 2.66 & 14.99 & 0.05 & 0.00 & 0.00 & 0.00 & 0.00 & 0.00 & 96.41 \\
\hline 9 & $\mathrm{Ap}$ & 53.82 & 0.14 & 22.42 & 0.00 & 0.01 & 1.75 & 2.48 & 16.53 & 0.35 & 0.00 & 0.01 & 0.00 & 0.00 & 0.00 & 97.52 \\
\hline 10 & $\mathrm{Ap}$ & 53.09 & 0.00 & 23.30 & 0.11 & 0.00 & 1.20 & 2.53 & 15.91 & 0.60 & 0.00 & 0.00 & 0.08 & 0.18 & 0.37 & 97.37 \\
\hline 11 & $\mathrm{Ap}$ & 53.65 & 0.00 & 21.90 & 0.00 & 0.00 & 0.73 & 1.93 & 17.16 & 0.29 & 0.02 & 0.00 & 0.00 & 0.39 & 0.00 & 96.19 \\
\hline 12 & $\mathrm{Cpx}$ & 54.75 & 1.00 & 20.15 & 4.76 & 1.90 & 7.41 & 4.57 & 5.34 & 0.00 & 0.03 & 0.00 & 0.00 & 0.00 & 0.00 & 99.91 \\
\hline 13 & $\mathrm{Cpx}$ & 55.53 & 0.24 & 21.60 & 1.96 & 0.97 & 3.30 & 4.77 & 4.94 & 0.00 & 0.07 & 0.00 & 0.00 & 0.00 & 0.00 & 93.38 \\
\hline 14 & $\mathrm{Cpx}$ & 55.53 & 0.26 & 21.93 & 1.66 & 1.00 & 3.53 & 4.83 & 5.69 & 0.00 & 0.08 & 0.00 & 0.00 & 0.00 & 0.00 & 94.51 \\
\hline 15 & $\mathrm{Cpx}$ & 56.06 & 0.11 & 22.87 & 0.90 & 0.32 & 1.77 & 4.54 & 7.48 & 0.00 & 0.11 & 0.00 & 0.00 & 0.00 & 0.00 & 94.16 \\
\hline 16 & Amp & 55.02 & 0.10 & 22.45 & 0.68 & 0.17 & 2.95 & 4.59 & 7.52 & 0.58 & 0.07 & 0.00 & 0.00 & 0.00 & 0.00 & 94.13 \\
\hline
\end{tabular}

Примечание. Включения в минералах: 1-3 - шонкинитов; 4 - псевдолейцитовых сиенитов; 5-11 - апатитовых шлиров и обособлений: в сынныритах (5, $9,11)$, пироксенитах $(6,7,10)$, шонкинитах (8); 12-16 - мончикитов-камптонитов. Включения: 1-4 - гомогенизированные, 5-11 - прогретые до 1050$1180^{\circ} \mathrm{C}$ и закаленные, 12-16 - не гретые (12 - стекловатые включения, 13-16 - остаточные стекла частично раскристаллизованных включений). 
Таблица 4. Состав флюидной фазы включений в минералах сынныритов

\begin{tabular}{|c|c|c|c|c|c|c|c|c|c|c|c|}
\hline \multirow[t]{2}{*}{$\mathrm{N}, \mathrm{N}$} & \multirow[t]{2}{*}{$\mathrm{T}^{0} \mathrm{C}$ нагрева } & \multicolumn{10}{|c|}{ Содержание, мг/кг } \\
\hline & & $\mathrm{CO}_{2}$ & $\mathrm{H}_{2} \mathrm{O}$ & $\mathrm{H}_{2}$ & $\mathrm{~N}_{2}$ & $\mathrm{CH}_{4}$ & $\mathrm{CO}$ & $\mathrm{H}_{2} \mathrm{~S}$ & $\mathrm{SO}_{2}$ & $\mathrm{C}_{2} \mathrm{H}_{2}$ & $\mathrm{NH}_{3}$ \\
\hline 1 & 920 & 4051.0 & 396.8 & 0.0 & 0.0 & 0.0 & 83.7 & 0.0 & 0.0 & сл.углеводородов & 0.0 \\
\hline 2 & 900 & 1751.8 & 377.0 & 0.0 & сл. & 0.0 & 52.8 & 0.0 & 0.0 & сл.углеводородов & 0.0 \\
\hline 3 & 890 & 3032.9 & 643.6 & 0.0 & 0.0 & 0.0 & 42.7 & 0.0 & 0.0 & 0.0 & 0.0 \\
\hline 4 & 870 & 365.5 & 179.6 & 0.0 & сл. & 0.0 & 30.8 & 0.0 & 0.0 & 0.0 & 0.0 \\
\hline 5 & 850 & 284.3 & 212.9 & 0.0 & 0.0 & 0.0 & 28.8 & 0.0 & 0.0 & 0.0 & 0.0 \\
\hline 6 & 830 & 334.6 & 129.0 & 0.0 & сл. & 0.0 & 60.6 & 0.0 & 0.0 & 0.0 & 0.0 \\
\hline 7 & 780 & 78.9 & 173.5 & 0.0 & 0.0 & 0.0 & 11.7 & 0.0 & 0.0 & 0.0 & 0.0 \\
\hline 8 & 620 & 56.2 & 105.0 & 0.0 & сл. & 1.4 & 2.4 & 0.0 & 0.0 & сл. & сл. \\
\hline 9 & 600 & 25.2 & 173.7 & 0.0 & 0.0 & 1.2 & сл. & 0.0 & 0.0 & 0.0 & 0.0 \\
\hline 10 & 580 & 33.9 & 81.9 & 0.0 & 0.0 & 0.0 & 0.0 & 0.0 & 0.0 & 0.0 & 0.0 \\
\hline 11 & 440 & 6.5 & 106.7 & 0.0 & 0.0 & 0.0 & 3.3 & 0.0 & 0.0 & 0.0 & 0.0 \\
\hline 12 & 350 & 8.9 & 97.0 & 0.0 & 5.6 & 0.0 & 3.6 & 0.0 & 0.0 & 0.0 & 0.0 \\
\hline
\end{tabular}




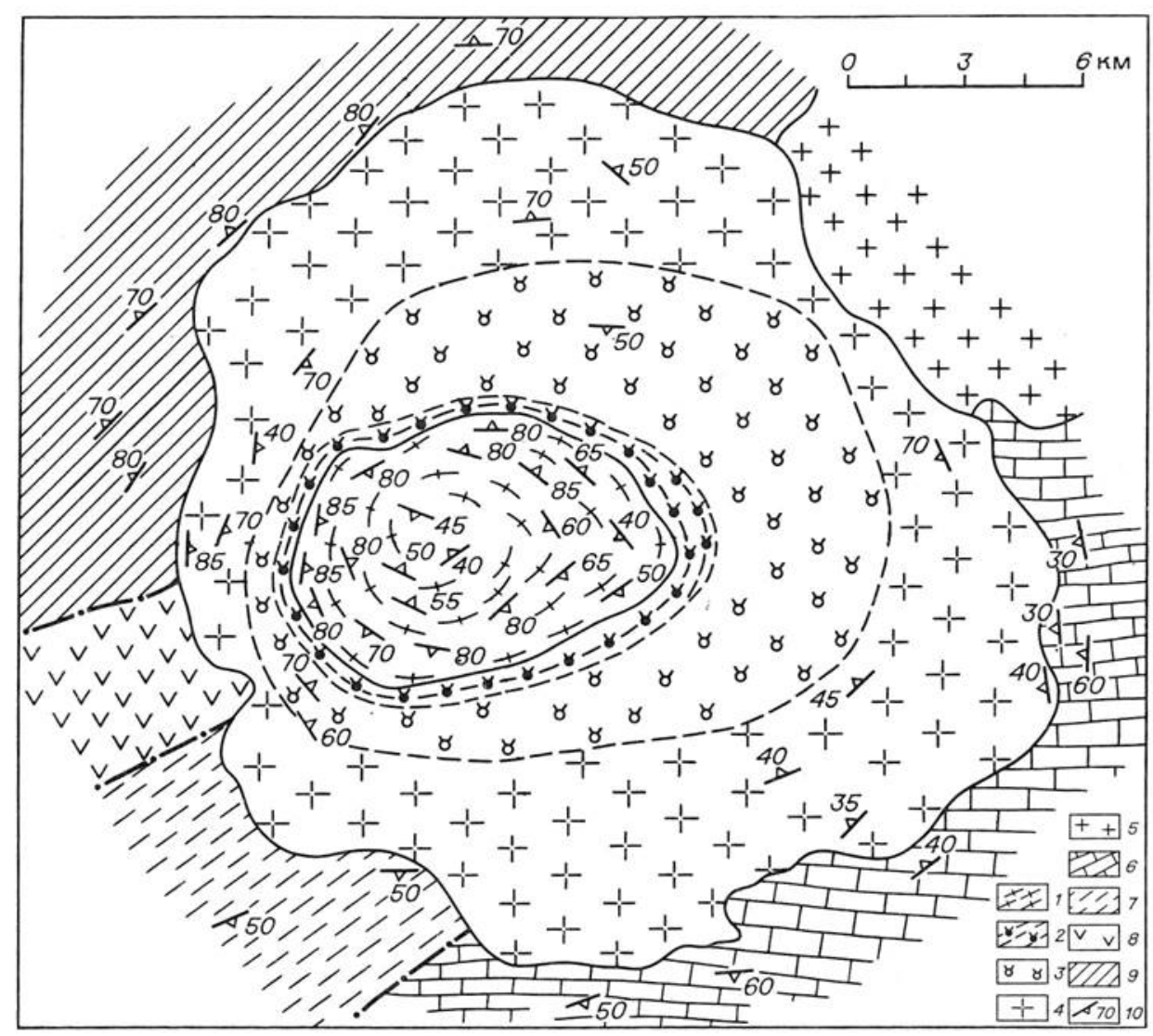

Рис. 1. Строение Сыннырского массива (Костюк и др., 1990). 

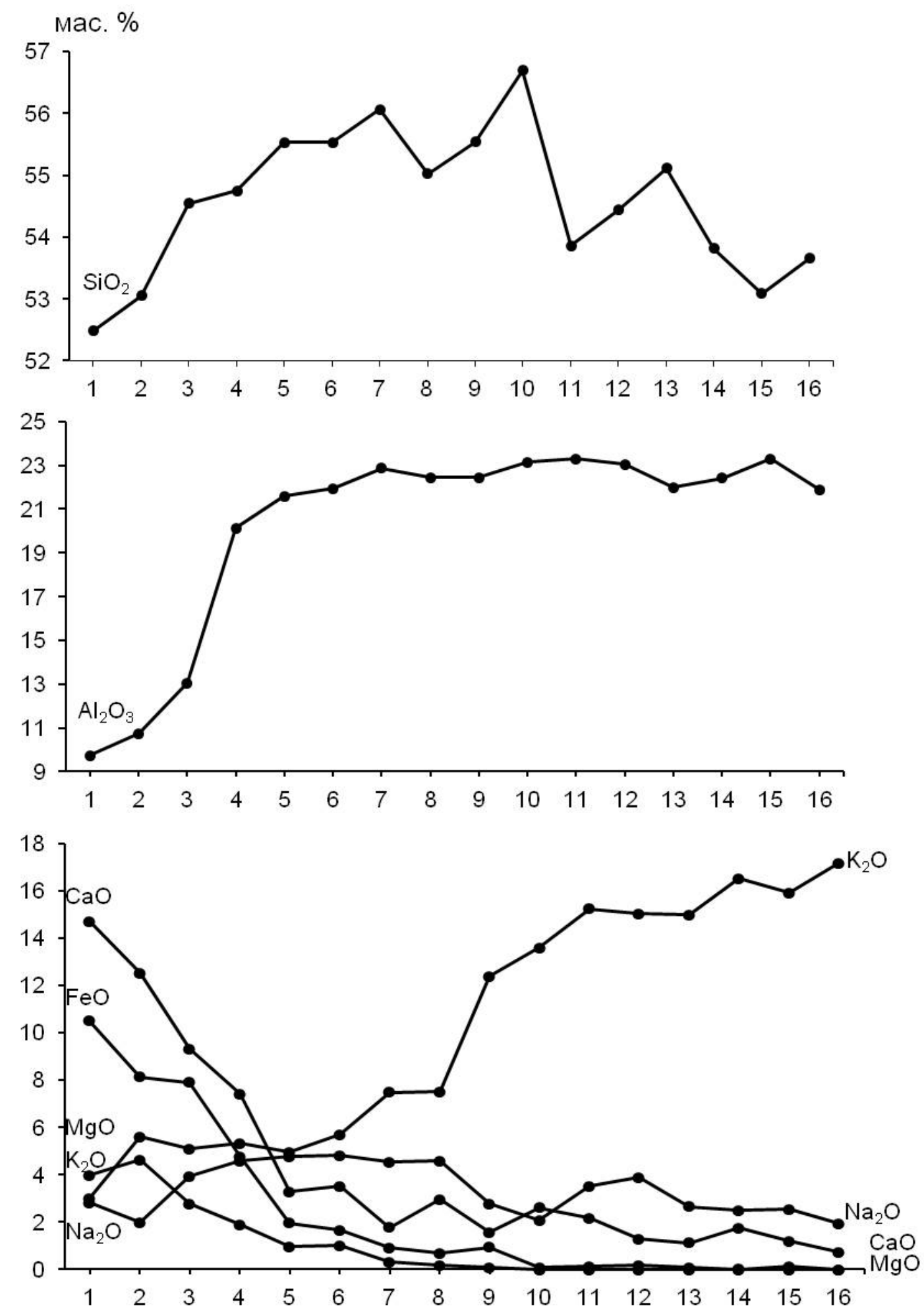

Рис. 2. Эволюционное преобразование материнской магмы при формировании пород Сыннырского массива. 


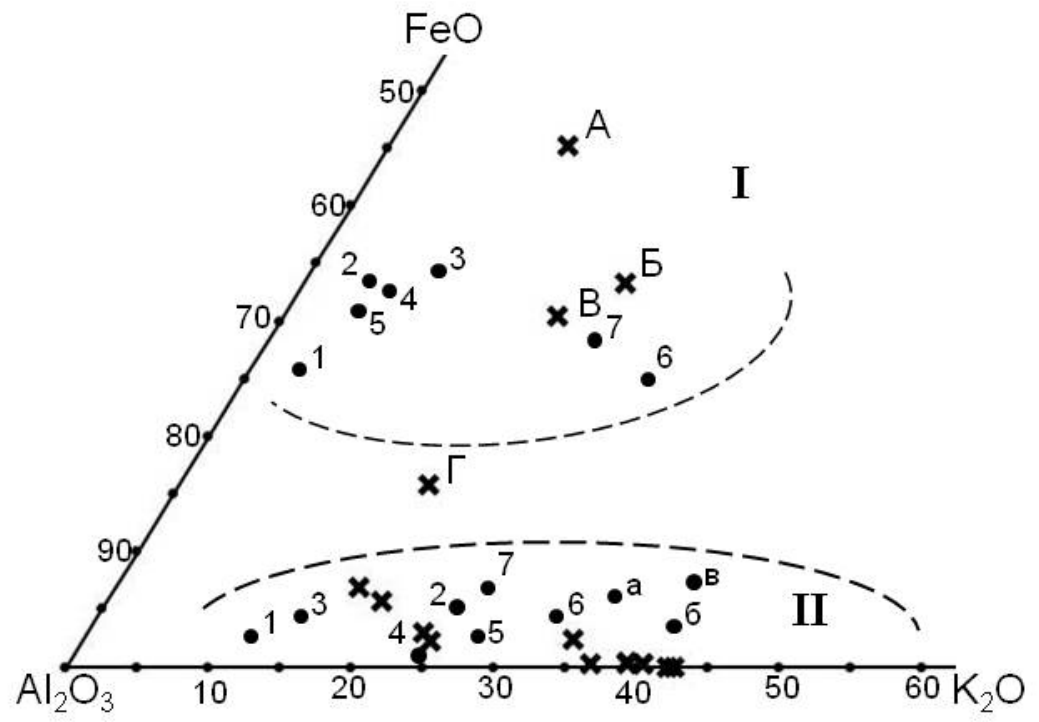

Рис. 3. Положение составов щелочных базальтоидов (I), их остаточных стекол (II) и законсервированных расплавов в минералах сыннырских пород в системе $\mathrm{Al}_{2} \mathrm{O}_{3}-\mathrm{FeO}-\mathrm{K}_{2} \mathrm{O}$. 